\title{
Graphite Gamma Scan Results
}

\author{
Mark W. Drigert
}

April 2014
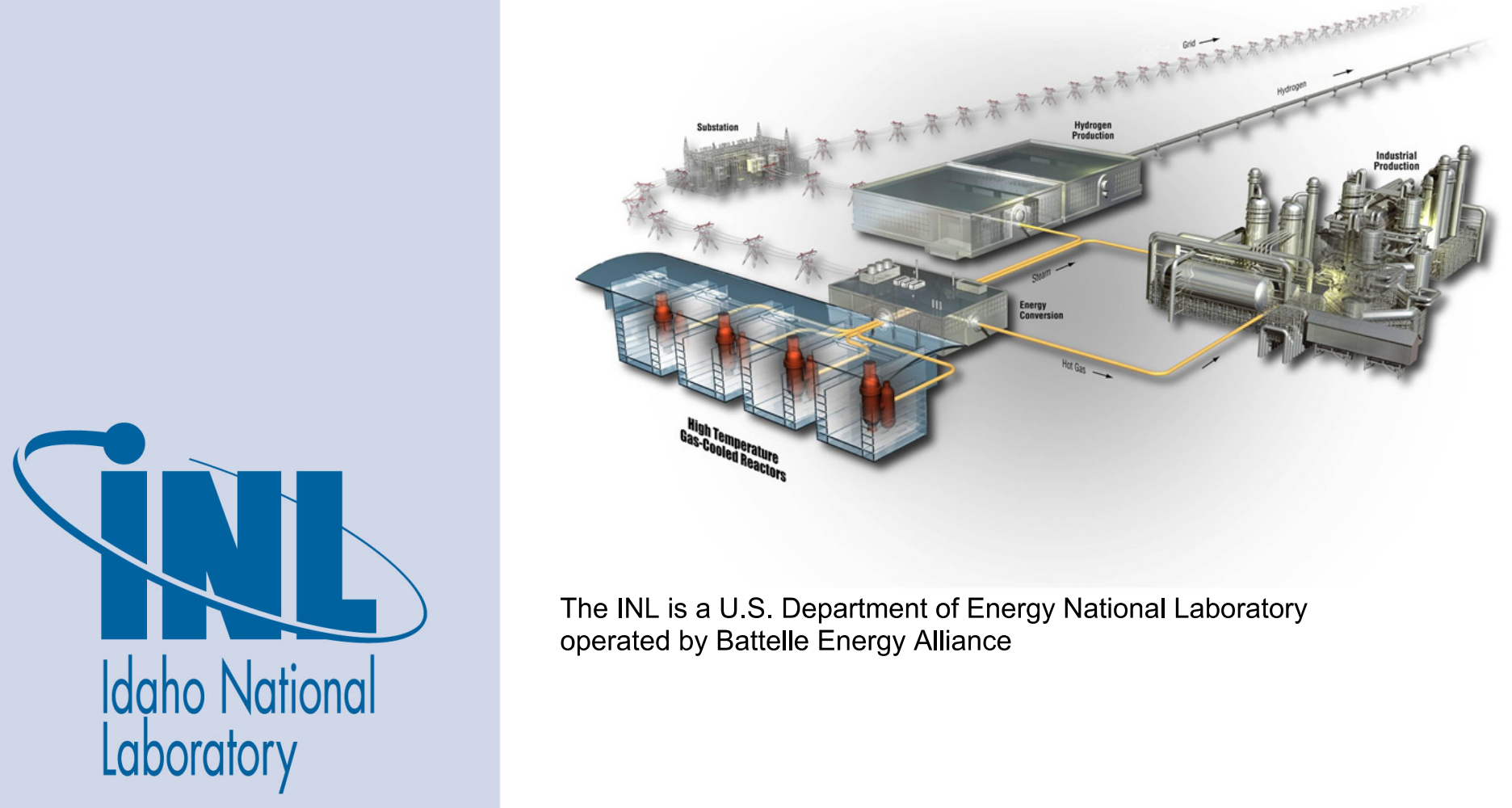

The INL is a U.S. Department of Energy National Laboratory operated by Battelle Energy Alliance 


\section{DISCLAIMER}

This information was prepared as an account of work sponsored by an agency of the U.S. Government. Neither the U.S. Government nor any agency thereof, nor any of their employees, makes any warranty, expressed or implied, or assumes any legal liability or responsibility for the accuracy, completeness, or usefulness, of any information, apparatus, product, or process disclosed, or represents that its use would not infringe privately owned rights. References herein to any specific commercial product, process, or service by trade name, trade mark, manufacturer, or otherwise, does not necessarily constitute or imply its endorsement, recommendation, or favoring by the U.S. Government or any agency thereof. The views and opinions of authors expressed herein do not necessarily state or reflect those of the U.S. Government or any agency thereof. 
INL/EXT-14-31843

Revision 0

\title{
Graphite Gamma Scan Results
}

\author{
Mark W. Drigert
}

April 2014

\begin{abstract}
Idaho National Laboratory
VHTR Program

Idaho Falls, Idaho 83415
\end{abstract}

http://www.inl.gov

\author{
Prepared for the \\ U.S. Department of Energy \\ Office of Nuclear Energy \\ Under DOE Idaho Operations Office \\ Contract DE-AC07-05ID14517
}



VHTR Program

\section{Graphite Gamma Scan Results}

\section{INL/EXT-14-31843}

Revision 0

April 2014

Approved by:
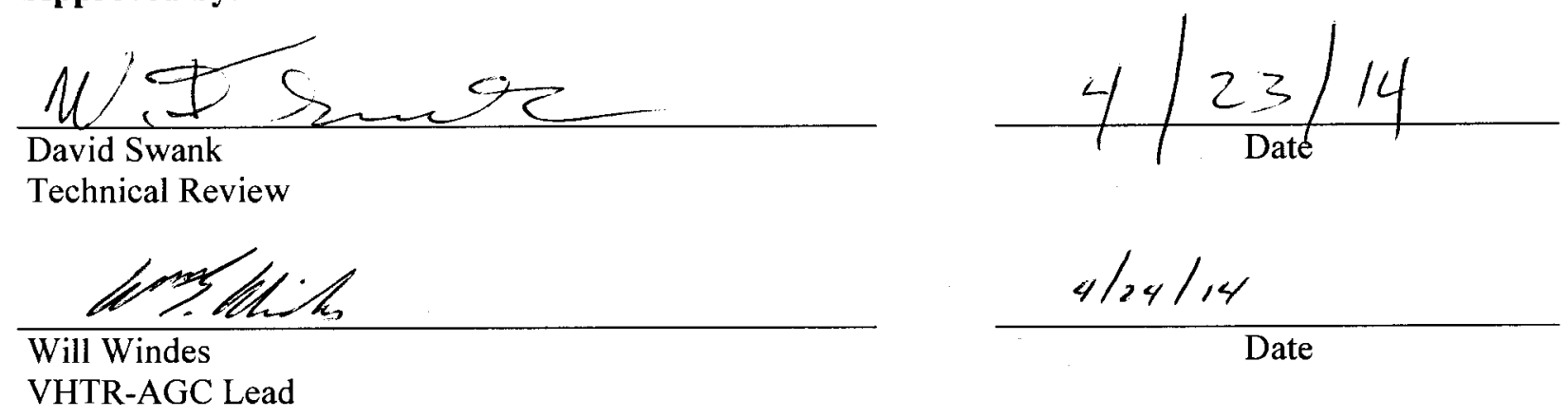



\section{SUMMARY}

This report documents the measurement and data analysis of the radio-isotopic content for a series of graphite specimens irradiated in the first Advanced Graphite Creep (AGC) experiment, AGC-1. This is the first of a series of six capsules planned as part of the AGC experiment to fully characterize the neutron irradiation effects and radiation creep behavior of current nuclear graphites. The AGC-1 capsule was irradiated in the Advanced Test Reactor (ATR) at INL at approximately $700^{\circ} \mathrm{C}$ and to a peak dose of $7 \mathrm{dpa}$ (displacements per atom). Details of the irradiation conditions and other characterization measurements performed on specimens in the AGC-1 capsule can be found in "AGC-1 Specimen Post Irradiation Data Report" ORNL/TM-2013/242. Two specimens from six different graphite types are analyzed here. Each specimen is $12.7 \mathrm{~mm}$ in diameter by $25.4 \mathrm{~mm}$ long. The isotope with the highest activity was ${ }^{60} \mathrm{Co}$. Graphite type NBG-18 had the highest content of ${ }^{60} \mathrm{Co}$ with an activity of $142.89 \mu \mathrm{Ci}$ at a measurement distance of $47 \mathrm{~cm}$. 


\section{CONTENTS}

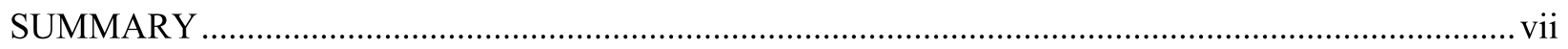

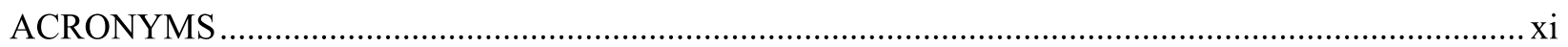

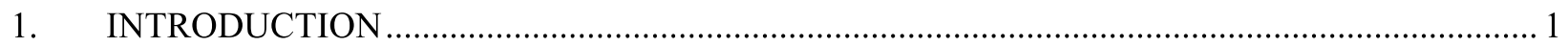

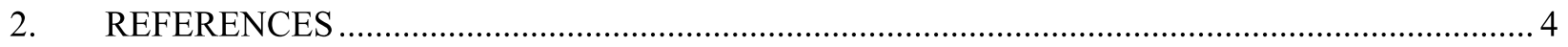

\section{TABLES}

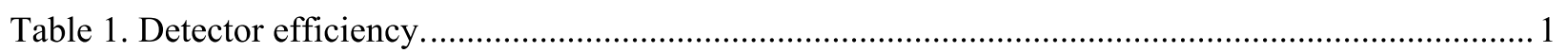

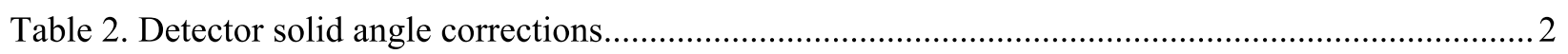

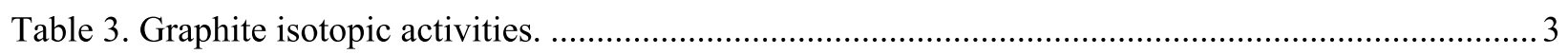

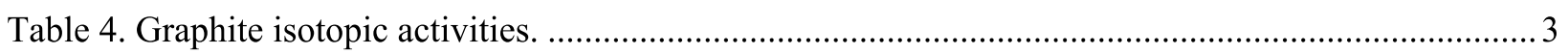

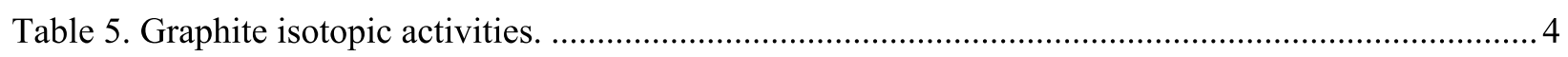




\section{ACRONYMS}

AGC Advanced Graphite Creep

AGR Advanced Gas Reactor

ATR Advanced Test Reactor

MCA Multi-channel Analyzer

PCGAP Personal Computer Gamma Analysis Package 


\section{Graphite Gamma Scan Results}

\section{INTRODUCTION}

This report documents the measurement and data analysis of the radio-isotopic content for a series of graphite specimens irradiated in the first Advanced Graphite Creep (AGC) experiment, AGC-1. It is the first of a series of six capsules planned as part of the AGC experiment to fully characterize the neutron irradiation effects and radiation creep behavior of current nuclear graphites. The AGC-1 capsule was irradiated in the Advanced Test Reactor (ATR) at INL at approximately $700^{\circ} \mathrm{C}$ and to a peak dose of $7 \mathrm{dpa}$ (displacements per atom). Details of the irradiation conditions and other characterization measurements performed on specimens in the AGC-1 capsule can be found in ORNL/TM-2013/242, "AGC-1 Specimen Post Irradiation Data Report." Two specimens from six different graphite types are analyzed here. Each specimen is $0.5 \mathrm{in}$. in diameter by $1.0 \mathrm{in}$. long. The measurements reported here were performed using a Princeton Gamma-Tech (PGT) Intrinsic Germanium detector. Data was collected using a standard Ortec DSpec jr 2.0 Multi-channel Analyzer (MCA) and controlled using Ortec GammaVision v5.31. Super_Panda 16k (June 11, 2010), which is part of the Personal Computer Gamma Analysis Package (PCGAP) suite of applications in use to monitor the effluent gas from the Advanced Gas Reactor (AGR) fuel qualification irradiations AGR-2,3/4 currently installed in the ATR was used to analyze the data.

The detector crystal was oriented in the vertical direction. It is $5.74 \mathrm{~cm}$ in length, with a diameter of $5.9 \mathrm{~cm}$. The surface area of the crystal exposed to the radiation from the graphite samples is $33.9 \mathrm{~cm}^{2}$. All measurements were performed with the sample placed at a vertical height to be centered in the middle of the long axis of the Ge crystal. The horizontal distance between sample and the detector were measured to the side of the detector end cap closest to the sample. Prior to the measurement of the graphite samples, an efficiency measurement was performed using a ${ }^{152}$ Eu standard (source ID: 724-10-15) in the IF-638 high bay. The uncertainty of the certified activity of the source is $3.3 \%$. For the efficiency measurements, the source was located $18.4 \mathrm{~cm}$ from the side of the detector end cap. Details of the calibration source and Ge detector can be obtained from ECAR-991, "Engineering Calculations and Analysis Report."

Table 1. Detector efficiency.

\begin{tabular}{|l|c|c|}
\hline Energy & Efficiency & $\begin{array}{c}\% \\
\text { Error }\end{array}$ \\
\hline 121.8 & $2.89 \mathrm{e}-3$ & 3.3 \\
\hline 244.7 & $2.23 \mathrm{e}-3$ & 3.3 \\
\hline 344.3 & $1.70 \mathrm{e}-3$ & 3.3 \\
\hline 411.1 & $1.36 \mathrm{e}-3$ & 3.3 \\
\hline 444.0 & $1.33 \mathrm{e}-3$ & 3.3 \\
\hline 778.9 & $8.32 \mathrm{e}-4$ & 3.3 \\
\hline 867.4 & $7.60 \mathrm{e}-4$ & 3.3 \\
\hline 964.1 & $5.08 \mathrm{e}-4$ & 3.3 \\
\hline 1085.8 & $6.32 \mathrm{e}-4$ & 3.3 \\
\hline 1112.9 & $6.21 \mathrm{e}-4$ & 3.3 \\
\hline 1212.9 & $5.79 \mathrm{e}-4$ & 3.3 \\
\hline 1299.1 & $5.55 \mathrm{e}-4$ & 3.3 \\
\hline 1408.0 & $5.13 \mathrm{e}-4$ & 3.3 \\
\hline
\end{tabular}


Table 1 details the detector efficiency determined from the ${ }^{152}$ Eu calibration. The efficiency reported is composed of two components: the intrinsic efficiency of the Ge crystal to gamma-rays that strike the crystal, which is dependent on gamma-ray energy, and the solid angle subtended by the Ge crystal. This is simply a measure of the fraction of the radiation emitted by the sample that actually hits the Ge crystal. The fraction scales inversely with the square of the sample to detector distance. Because of the large difference in the radiation strengths for the different graphite samples, the sample-to-detector distance was varied to keep the measurement systems dead-time below $30 \%$. The variations in the sample-to-detector distance will need to be factored into the isotopic inventories for the graphite samples.

The PCGAP program Super_Panda is designed take measured gamma-ray spectral data and output the activities in $\mu \mathrm{Ci}$ of the various radio-nuclides present in the sample. It does this by first fitting the photo-peak areas of the various gamma-ray lines present in the spectrum (Killian and Harwell 2000). The program corrects the fitted peak areas with the measured efficiency calibration to determine the gamma-ray flux incident on the detector. It then compares the gamma-ray energy of fitted photo-peak areas to the values listed in an extensive library to determine the possible radionuclide that is the source of the fitted gamma ray. If there are multiple possible radio-isotopes, then all the possibilities are listed. For each possible isotope, the library contains information about the emission probability of the particular gamma ray. This information is used to determine an activity for that isotope. If more than one gamma-ray belonging to a particular isotope is found, activities are computed for each gamma ray independently. A weighted average of the activities derived from the individual gamma rays is computed to determine the final isotopic activities.

Table 2. Detector solid angle corrections

\begin{tabular}{|l|c|c|c|}
\hline $\begin{array}{c}\text { Radius } \\
(\mathrm{cm})\end{array}$ & $\begin{array}{c}\text { Spherical Area } \\
\left(\mathrm{cm}^{2}\right)\end{array}$ & $\begin{array}{c}\text { Solid } \\
\text { Angle } \\
\text { Fraction }\end{array}$ & $\begin{array}{c}\text { Corr. } \\
\text { Factor }\end{array}$ \\
\hline 18.4 & 4254.5 & 0.0080 & 1.0 \\
\hline 10.0 & 1256.6 & 0.0269 & 0.295 \\
\hline 11.0 & 1520.5 & 0.0223 & 0.357 \\
\hline 11.5 & 1661.9 & 0.0204 & 0.391 \\
\hline 15.0 & 2827.4 & 0.0120 & 0.665 \\
\hline 23.0 & 6647.6 & 0.0051 & 1.563 \\
\hline 40.0 & 20106.2 & 0.0017 & 4.726 \\
\hline 47.0 & 27759.1 & 0.0012 & 6.525 \\
\hline
\end{tabular}

By making a comparison of the analysis results with the accepted decay information available from the Nuclear Data Center at Brookhaven National Laboratory, the determination of proper radioisotope association with a particular fitted gamma-ray was made. The isotopic activities obtained from the PCGAP software were then scaled with the solid angle corrections listed in Table 2.

The uncertainties in the reported isotopic activities are a mixture of the PCGAP reported uncertainties and the overall uncertainty in the ${ }^{152} \mathrm{Eu}$ source used to efficiency calibrate the Ge detector. Tables 3-5 contain the results for the 12 graphite samples measured, and indicate the sample-to-detector measurement distances used for each graphite sample. Any isotopes that had an activity level below $0.01 \mu \mathrm{Ci}$ was excluded from the table. 
Table 3. Graphite isotopic activities.

\begin{tabular}{|l|c|c|c|c|c|c|c|c|}
\hline \multicolumn{1}{|c|}{ Isotope } & \multicolumn{2}{c|}{$\begin{array}{c}\text { AW7-02 } \\
\text { NBG-17 }\end{array}$} & \multicolumn{2}{c|}{$\begin{array}{c}\text { AW9-02 }(47 \mathrm{~cm}) \\
\text { NBG-17 }\end{array}$} & \multicolumn{2}{c|}{$\begin{array}{c}\text { BW8-03 }(47 \mathrm{~cm}) \\
\text { NBG-18 }\end{array}$} & \multicolumn{2}{c|}{$\begin{array}{c}\text { BW11-03 }(47 \mathrm{~cm}) \\
\text { NBG-18 }\end{array}$} \\
\hline & $\mathrm{I}(\mu \mathrm{Ci})$ & \%err & $\mathrm{I}(\mu \mathrm{Ci})$ & $\%$ err & $\mathrm{I}(\mu \mathrm{Ci})$ & $\%$ err & I $(\mu \mathrm{Ci})$ & $\%$ err \\
\hline${ }^{46} \mathrm{Sc}$ & 1.72 & 3.4 & 3.70 & 3.3 & 5.00 & 3.3 & 9.87 & 3.4 \\
\hline${ }^{54} \mathrm{Mn}$ & 1.47 & 3.3 & 2.91 & 3.5 & 2.52 & 3.3 & 4.76 & 3.3 \\
\hline${ }^{60} \mathrm{Co}$ & 55.20 & 3.3 & 104.33 & 3.3 & 77.90 & 3.3 & 142.89 & 3.3 \\
\hline${ }^{65} \mathrm{Zn}$ & 0.31 & 4.4 & 0.23 & 14.1 & 0.28 & 9.8 & 0.17 & 31.6 \\
\hline${ }^{95} \mathrm{Zr}$ & 0.12 & 8.1 & - & - & 0.14 & 8.5 & 0.16 & 11.9 \\
\hline${ }^{95} \mathrm{Nb}$ & 0.06 & 9.1 & 0.14 & 7.6 & 0.15 & 5.4 & 0.31 & 4.6 \\
\hline${ }^{110 \mathrm{~m}} \mathrm{Ag}$ & 0.12 & 4.3 & 0.09 & 6.8 & 0.08 & 7.2 & - & - \\
\hline${ }^{134} \mathrm{Cs}$ & 1.37 & 3.3 & 2.21 & 3.3 & 3.77 & 3.3 & 5.21 & 3.3 \\
\hline${ }^{137} \mathrm{Cs}$ & 0.07 & 7.0 & 0.12 & 7.9 & 0.13 & 6.4 & 0.25 & 5.2 \\
\hline${ }^{144} \mathrm{Ce}$ & 0.02 & 13.9 & 0.55 & 6.6 & 0.50 & 5.3 & 1.15 & 4.2 \\
\hline${ }^{154} \mathrm{Eu}$ & 0.76 & 3.5 & 0.28 & 5.1 & 0.98 & 3.6 & 0.41 & 3.9 \\
\hline
\end{tabular}

Table 4. Graphite isotopic activities.

\begin{tabular}{|l|c|c|c|c|c|c|c|c|}
\hline \multirow{2}{*}{ Isotope } & \multicolumn{2}{c|}{$\begin{array}{c}\text { CW11-03 } \\
(23 \mathrm{~cm})\end{array}$} & \multicolumn{2}{c|}{$\begin{array}{c}\text { CW12-01 } \\
(11.5 \mathrm{~cm})\end{array}$} & \multicolumn{2}{c|}{$\begin{array}{c}\text { DW9-02 } \\
(15 \mathrm{~cm}) \\
\text { H-451 }\end{array}$} & \multicolumn{2}{c|}{$\begin{array}{c}\text { DW10-03 } \\
(10 \mathrm{~cm}) \\
\text { PCEA }\end{array}$} \\
\hline & $\mathrm{I}(\mu \mathrm{Ci})$ & $\% \mathrm{err}$ & $\mathrm{I}(\mu \mathrm{Ci})$ & $\%$ err & $\mathrm{I}(\mu \mathrm{Ci})$ & $\%$ err & $\mathrm{I}(\mu \mathrm{Ci})$ & $\%$ err \\
\hline${ }^{46} \mathrm{Sc}$ & 0.12 & 3.5 & 0.06 & 3.5 & 0.02 & 5.7 & 0.05 & 3.4 \\
\hline${ }^{54} \mathrm{Mn}$ & 1.22 & 3.3 & 0.56 & 3.3 & 0.04 & 4.5 & 0.03 & 3.5 \\
\hline${ }^{60} \mathrm{Co}$ & 13.84 & 3.3 & 6.68 & 3.3 & 11.87 & 3.3 & 3.67 & 3.3 \\
\hline${ }^{65} \mathrm{Zn}$ & 0.70 & 3.4 & 1.11 & 3.3 & 0.38 & 3.4 & 0.35 & 3.3 \\
\hline${ }^{95} \mathrm{Zr}$ & - & - & - & - & - & - & 0.01 & 7.9 \\
\hline${ }^{95} \mathrm{Nb}$ & - & - & - & - & - & - & 0.02 & 3.8 \\
\hline${ }^{110 \mathrm{~m}} \mathrm{Ag}$ & 0.67 & 3.3 & 0.27 & 3.3 & 0.02 & 4.4 & 0.02 & 3.4 \\
\hline${ }^{134} \mathrm{Cs}$ & 0.20 & 3.4 & 0.13 & 3.3 & 0.01 & 8.8 & 0.03 & 3.4 \\
\hline${ }^{137} \mathrm{Cs}$ & - & - & - & - & 0.01 & 9.2 & 0.02 & 3.5 \\
\hline${ }^{144} \mathrm{Ce}$ & - & - & 0.01 & 12.4 & 0.02 & 8.0 & 0.10 & 3.4 \\
\hline${ }^{154} \mathrm{Eu}$ & 0.02 & 8.0 & 0.03 & 3.6 & 0.03 & 4.1 & - & - \\
\hline
\end{tabular}


Table 5. Graphite isotopic activities.

\begin{tabular}{|l|c|c|c|c|c|c|c|c|}
\hline & \multicolumn{2}{|c|}{$\begin{array}{c}\text { EW6-02 } \\
(11 \mathrm{~cm})\end{array}$} & \multicolumn{2}{c|}{$\begin{array}{c}\text { EW7-03 } \\
(11 \mathrm{~cm})\end{array}$} & \multicolumn{2}{c|}{$\begin{array}{c}\text { FW8-03 } \\
(11.5 \mathrm{~cm})\end{array}$} & \multicolumn{2}{c|}{$\begin{array}{c}\text { FW12-02 } \\
(10 \mathrm{~cm})\end{array}$} \\
Isotope & \multicolumn{2}{|c|}{$\mathrm{IG}-110$} & \multicolumn{2}{c|}{$\begin{array}{c}\text { IG-110 } \\
\text { IG-430 }\end{array}$} & \multicolumn{2}{c|}{ IG0 } \\
\hline & $\mathrm{I}(\mu \mathrm{Ci})$ & $\%$ err & $\mathrm{I}(\mu \mathrm{Ci})$ & $\%$ err & $\mathrm{I}(\mu \mathrm{Ci})$ & $\%$ err & $\mathrm{I}(\mu \mathrm{Ci})$ & $\%$ err \\
\hline${ }^{46} \mathrm{Sc}$ & 0.01 & 5.1 & 0.03 & 3.7 & 0.02 & 3.4 & 0.01 & 3.6 \\
\hline${ }^{54} \mathrm{Mn}$ & 0.06 & 3.7 & 0.05 & 3.5 & 0.01 & 3.5 & 0.04 & 3.3 \\
\hline${ }^{60} \mathrm{Co}$ & 4.62 & 3.3 & 8.60 & 3.3 & 0.92 & 3.3 & 1.17 & 3.3 \\
\hline${ }^{65} \mathrm{Zn}$ & 0.57 & 3.3 & 0.55 & 3.3 & 0.18 & 3.3 & 0.17 & 8.1 \\
\hline${ }^{110 \mathrm{~m}} \mathrm{Ag}$ & 0.05 & 3.4 & 0.06 & 3.4 & 0.01 & 3.4 & 0.01 & 3.4 \\
\hline${ }^{134} \mathrm{Cs}$ & - & - & 0.01 & 4.5 & - & - & - & - \\
\hline${ }^{137} \mathrm{Cs}$ & 0.02 & 4.1 & - & - & 0.02 & 3.3 & 0.02 & 3.4 \\
\hline${ }^{154} \mathrm{Eu}$ & 0.45 & 3.3 & 0.14 & 3.4 & - & - & 0.02 & 3.4 \\
\hline
\end{tabular}

\section{REFERENCES}

ECAR-991, "Engineering Calculations and Analysis Report," Idaho National Laboratory, May 2010.

Killian E. W., and J. K. Hartwell, "PCGAP: Users Guide and Algorithm Description," INEEL/EXT-2000-00908, Idaho National Laboratory, September 2000.

ORNL/TM-2013/242, “AGC-1 Specimen Post Irradiation Data Report, Oak Ridge National Laboratory, Year. 